\title{
Ngabungbang Ritual Culture in Peasant Communities
}

\author{
Shindu Irwansyah ${ }^{1 *}$,Hadi Nuramin ${ }^{2}$, Dede Wahyudin ${ }^{3}$ \\ 1Fakultas Syari'ah UNISBA \\ 2UIN Sunan Gunung Djati Bandung \\ 3ISIF Cirebon \\ *Corresponding author E-mail:shinduirwansyah@gmail.com
}

\begin{abstract}
The purpose of this study is to explore the purpose of carrying out the rituals of ngabungbangand increase the local wisdom of Sundanese people, especiallythe people of Cihideung. This research uses descriptive qualitative methods, data collection techniques used are observation, interviews, document studies, literature studies, namely by investigating and covering the analysis and interpretation of data to conclusions based on research. Humans basically have bad traits which must be cleaned in order to bring kindness, peace and comfort to other beings. Cihideung residents believe that spirits and spirits who occupy their place can give good or bad. ngabungbangis silent outside the buildingby staying up all night especially in the sacred place of the full moon calendar which is usually done on the fourteenth of the month of mulud because in this month the birth of the prophet Muhammad SAW. the mosque. The mourning ritual is still carried on from generation to generation which mediates the people of Cihideung to rid themselves of bad traits, stayaway from reinforcements in order to get good and be kept awayfrom the ugliness that befalls them when living life, and respecttheir spirits with media used as media symbol in ritual. The media in this ritual are offerings for the karuhun which consist of: Gapar mulud, Gapar Kabulan, Nyimbel Red and white porridge, bitter coffee, brown sugar, milk, and clear water, salt, rice cone, rice and money.
\end{abstract}

Keywords: culture, ritual, ngabungbang, Cihideung

\section{INTRODUCTION}

Humans, societyandculturearedialectically related. The threesideby side andcoincide create and eliminate each other, all three together to create a relationship of meaning. Their existence cannot be independent without being related to others. In that relationship, each experiences a loss of himself in a moment and then can reappear in another moment. The moment of externalization is the moment that encouragespeople to havethe ability to expressthemselves by building their world. Throughthismoment too, society becomesa realitycreatedby humans (Kahmad,2011).

Culture isthepowerof mindintheform of creativity, intention andtaste, whilecultureis theresult of creativity, intention, and taste (Afrianti, 2019). According to the science of cultural anthropology is the whole system of ideas, actions andresults of human work in the contextof community life that belongs to the human self by learning (Ghani, 2019). As quoted by Koentjaraningrat that Leslie White believes human behavior begins with the use of symbols (Koentjaraningrat, 1990). Art, religion and money involve the use of symbols.

For Sundanesepeople, Islam is aninseparable part of life, because for them to embrace Islam is like studying their own culture. This happened because of the similarity of the Islamic religion with the Sundanese character that existed at that time. According to Dadang Kahmad, there are two things that

\footnotetext{
* Copyright (c) 2020 Shindu Irwansyah et.all

This work is licensed under a Creative Commons Attribution-ShareAlike 4.0 International License.
} 
cause Islam to be easilyacceptedby Sundanese people. First, the teachings of Islam (Islamic teaching) are considered not complex even relatively simple so that they can be easily accepted and compatible with Sundaneseculture which is also simple. The teachings on the creed, worship and moralsin Islam arevery much in accordancewiththedynamicSundanesesoul. Second, theoriginalculturewhichis the"wrap" of Islam is Eastern culturethatis familiar to Sundanesepeople (Kahmad, 2011).

Religionisa patternof actionthat is something that livesinhumanbeingsthatappearsin their daily lives. Herereligionis consideredas part of thecultural system (Archer \& Elder-Vass, 2012). As quoted by Nur Syam, that Ignaz argues thattherelationshipbetweenthe patternfor andthepatternof the action lies in the symbol system thatallowsthemeaning to becarriedout (Syam, 2005).

According to Durkheim The sacred or sacred is something different from the profane, the sacred includes beliefs, myths, dogmas that express representations or representational systems in which the sacred nature contains forces symbolized by interrelation with the profane (Petrof, 2015). Religion, according to Durkheim, is a unity of belief and certain practices towards something sacred, such beliefs and practices unite the morals of a community called worshipers or the church. Belief in this sense are expressions that declare the sacred, while the practices (rites) of rules that determine how someone behavestowards the presence of holy objects (Mufid,2006). The symbols brought by the religion in turn give a certain motivation and mood to the people of the religion. Motivation and mood are long-lasting, pervasive, comprehensive andstronglyembeddedinhumans. In otherwords, symbols broughtby religion cause peopleto "feelsomething" andwant to "do something" (Riis \& Woodhead, 2010).

According to Koentjaraningrat that nature is a place where natural phenomena and events are considered by humans as a place of strength that exceeds the power that has been known to humans in the environment which is called the theory of extraordinary and supernaturalistic forces (Koentjaraningrat, 1990). Religion that is believed by the community can be part of the existing value system in theculture of the community. This valuesystem willbe thedriving force and thedriving force and controller for the actions of members of the community, so that religious individuals are considered as part of their way of life in living their lives. The norms and values are symbolically displayed through demonstrationsin theform of ceremonies performed by the community. So thattheceremony awakens a sense of security for residents in their environment, and can also be used as a handle in daily behavior (Ismail, 2012).

The majority of the people of Cihideung work as ornamental plant farmers and are Muslim but still believein supernatural powers thathave a great influenceon themselves and the environment. They understandthat theuniverse is occupied by spirits and supernatural powersthatcan bring good or bad. Water is sacred to them andimportantbecausetheirlivesareverydependent on the water source. From here they thenholdrituals to get the purposetheywantsuchas to honor, be gratefulfor, and ask for the salvation of the spirits of their ancestorswho havecontributed. Many ritualsarerelatedto the life cycle or refuse reinforcements, where they contain elements that are not from the religion of Islam itself but are associated withlocalbeliefs. The belief system thatis still livedby the Cihideung community functions to regulate attitudes and value systems of life, so that elements of Religion and elements of original belief (customs) are mutually integrated (Wibowo, 2019).

This is unique to bestudiedbecausein themidstof modern life they are still usingit ingetting their life goals by performing rituals that are believed to be primitive by the ancients. One of the rituals performed by the Cihideung community is thengabungbang ritual. This ritual is foundin severalregions in West Java, but there are unique differences with the ngabungbang rituals performed in the Cihideung area. Therefore, theauthors areinterestedinresearching more aboutthe ritualof ngabungbang associated 
with themeaning, meaning, symbolscontainedin the ritualof ngabungbang, thefunctionof theirlives, and soon.

Some researches related to local wisdom havebeencarried outby previous researchers, including research on the rituals of ngabungbang. This research was conducted by galih nalurita and tati narawati (2010) in different places, namely Batulawang Banjar area with the theme of the function of ronggeng ibing in the ngabungbang ceremony in Batulawang Village, Kota Banjar, and the focus of the research raised by thesetwo writersis the realm of art about theaesthetic value of ronggengin the ngabungbang ceremony, while the research I conducted in this article is related to the sociological realm. Lina Herlinawati (2011) conducted research in the Cihideung area, this study discusses cleaning and maintaining water sources that are a source of life for the people of Cihideung. The difference of this research with previousresearchtalksabouttheritualsof ngabungbangassociatedwiththebirthday of the Prophet Muhammad in terms of time and the differences in performing rituals and interpreting ngabungbang itself.

\section{METHODOLOGY}

The research used is descriptive, descriptive research is research aimed at describing the phenomena or events in the form, activities, characteristics, relationships, security, similarities and changes that are natural or made in a state that is and the impact that occurs between one event or phenomenon with another (Sugiyono, 2013) . in other words descriptive research seeks to explain the phenomenathatoccurin thefieldnamely about thestructure, conditions and proceduresfor carrying out the rituals of ngabungbang. The location of this research is in Cihideung Village, Parongpong District. Qualitativemethod, whichis a method used to investigateand solve problems thatare not limited to the collectionandcompilationof data, butincludestheanalysis and interpretationof data to conclusions based on research.

The purposeof this study is to explore the purposeof carryingout therituals of ngabungbangand increase the local wisdom of Sundanese people, especially the people of Cihideung. The scope of this research is related to the scope of the material, namely all matters related to the name of the ceremony, the purposeandpurpose, thetime, the places wherethe ritual is performed, thetoolsin the ceremony, as well as thepeoplewho carryout the ceremony, thecourseof the ritual, restrictions restrictions thatmust be obeyed aswell asthemeaning containedin ritualsymbols.

Data collectiontechniques usedare by 1 . Observation, where researchersare directly involved with the peopleobservedor usedas researchsources. This observationactivitywas started by the researcher on November 20, 2017. In this case the researcher witnessed the ritual of mourning by conducting interviews with Alah Aling as he was in the village of Cihideung Kec. Parongpong district West Bandung. After observing the researchers found problems about the activities and meaning of the ngabungbang ritual. 2. Interview, the interview used in this study uses unstructured interviews based on the broad outlineof the questionsraisedby theinterviewees. 3. Document studies, in thisstudy researcherscollected documents in the form of photos, videos, audio related to ngabungbang rituals. 4. Literature study, this study is obtained through the existing literature in books, scientific works, research results, written sources bothprint andelectronic. 


\section{RESULTS AND DISCUSSION}

\section{State and Village of Cihideung Community}

The name Cihideung comes from the word caina hideung (Sundanese) which means the water is black. In thepastpeople intheareahadyellowteethbecause of caina peureu (cainahaseum, kesed) from the center of thewater(in Ciburial). Thedevelopmentof the populationis also growingwith the opening of land for settlements. As a fertile high / mountainous area, the potential of water and water resources owned are rivers and springs with a large discharge respectively. Both of these resources are used by residents to meet their agricultural needs and daily life. Cihideung Village has a population of 12,912 people, consisting of 6,150 men and 6,762 women. All of them are divided into 4,258 households. From the number and area, it can be seen the population density per $\mathrm{km}$, which is 344 people. In accordance with the state of the natural environment, the majority of the residents of Cihideung Village are farmers. (Cihideung Village and Village Development Data, 2009). From thesedata, it appears thatthemajority of the populationuses springs intheirarea to fulfilltheir daily needs.

So famous is the ornamental plant of Cihideung that it has become one of the popular tourist destinations in West Bandung Regency; for thepeopleof Cihideung Village, it wasa gift from the Creator. Because most of their lives are generated from natural resources, many important insights are always transmitted hereditary in maintaining the stability of nature through plants and water, as said by Abah Aling.

"Old-fashioned, elegant, makesense, engeoge makes sense, butthe sensearrives, makes sense, too pretentious," read the battle (bitter melon, jagong, boled, chilli, ignorant) "kahayangna kumaha, where ayana, naah daharna goods. Piren cenah God God tea nyiptakeun heaven jeung bumi tea, read sabaraha tens of forms of dahareun and so sabab keur enjoyment of urang inhalation. Tina Maca's eyes are in the seagrass in Bukukeun Tea, you can have books, even as a result of your discipline (major / study program). For example urak melak seedlings, jleug we dina jero taneuh huwi tea, timana eta tea must not be the cause of God, pomping ngalanggar kgal ngalanggar kana parent of God, mother parentahna must be run ". Interview with Abah Aling (Elders in Cihideung Village,Parongpong District, West Bandung Regency) 20 November 2017."

The condition of the community and the Cihideung area has changed a lot since the tourism sites were built up. Manyof the peoplesold theirland just to buy materialfor the sakeof their craving, so that many of the people who now only become agricultural laborers are no longer landowners. This understanding continues to be given by Abah Alingto thefamilyso that they continueto maintain theplant as a concept of affection for theiroffspring so thatthey canstill live properly.

"Beautiful ayeunamah loba, so I use mind / science, saeutik and I make a sense of feeling, feelgood, and be old-fashioned like a ge geun manunteunaneed urang, so sanajan outsidetheehhhsiungna deui we, da hakan sugging at me, it means that it is defective ge apaleun mun manusa tea needs urang, so sanajan outside the ehhh siungna deui we, da hayang ngugemake use anu meaningful, but kiwari mah bisabab rasana less, mangka sakali outsideof tea paehwe. Intheeraof kiwari mah pamahamana, teawas blocked outsideof tea, so we were mundedes untilkahandapnage paeh, da apaleun mun urang become deui moal benefits. Interview with Abah Aling (Elders in Cihideung Village, Parongpong District, West Bandung Regency) 20 November 2017"

\section{Religious System and Community Social Life}

Cihideung Village residentswho havea belief system inheritedfrom theirancestors, havetheir own views aboutthe concepts of natureand humans. Nature, intheconceptof cosmology, theyaredivided into 
two, namelythe naturalworldandthesupernatural. Thenatural world or real world isinhabitedby living things, suchas humans, animals, plants, including tangibleobjects thatcan be seen. The supernatural is a realm thatis inhabited byspirits suchas thespiritsof karuhun, jinn, demons, andghostsor dedemites. In addition they also believe in the existence of holy spirits that control certain places and objects that are closely relatedto humanlife, suchas those thatinhabitthe Sirawan Bangawan namely Mrs. Inang Saketi, Dayang Sumbi, Mrs. Lametan, Eyang Prabu Susuk Tunggal, Eyang Putih, and others. (Patanjala Journal, Vol. 3, June 2011).

Accordingto theirbeliefs, humans canmakecontactand establishcommunicationwiththespirits above. Likethespiritsof the ancestors who could beinvited to ask for help. On thecontrary, thespirits of the ancestors canbringdisaster intheform of disaster and disasterfor them, if the prohibitionis violated that is why, residents always maintain their relationship with the ancestral spirit through various traditionalrituals thatare routinely carriedout. Ritual activities inthe form of traditional ceremonies are held at certaintimesandroutinely carriedout is for the sake of ensuringthecomplianceof the citizens of social institutions. Theforms of theceremony appear inaddition to the beliefin the Creatorand the belief in the existence of an unseen world. Unseen world that is difficult to reach human reason, occupied by spirits whose strength can be useful or cause disaster or disaster. Spirits can be good spirits, evil spirits, ghosts, jinn. Good spirits include spirits of ancestors / ancestors or karuhun. In addition to carrying out traditional ceremonies intended to ask for blessings to the unseen, also to establish good relations so as not to disturb them. (Patanjala Journal,Vol. 3, June2011).

Accordingto Dhanavony, seeing rituals in fourcategories 1) the actof magicis associatedwiththe use of materials thatwork becauseof mysticalpower. 2)religious actions, ancestral cultsalso do thesame thing in a mystical way. 3) constitutive rituals which express or change social relations by referring to mysticalnotions, thespecificationsof this methodareclearer. 4) factitiveritualassociated withincreased productivity, strengthor purificationandprotection, othertermsarerelatedto the problem of increasing welfare(Ahimsa-Putra,2012).

Accordingto Koentjaraningratritual is a procedurein a ceremony or a sacred act carried out by a group of religious people. This activity is marked by the existence of various elements and components, namely the time, the places where the ceremony is performed, the tools in the ceremony, as well as the people who run the ceremony (Koentjaraningrat, 1990). Rituals or rites are performed with the aim of gettinga lot of blessingsor fortunefrom a job. Likea ceremony rejecting reinforcements andceremonies becauseof changes or cycles inhuman lifesuchas birth, marriage, anddeath.

Ngabungbang comes from the words "nga" and "bungbang". "Nga" means to exclude or unite. "Bungbang" meansto disposeor clean. Whichmeans, Ngabungbang is a sacred bath withthe intention to unite the creativity, taste, andintentionto getridof all the badbehaviorboth physicallyandmentally.

\section{Ngabungbang rituals}

Humans basically have bad qualities that must be cleansed in order to bring good, peace and comfort to otherbeings. Thegood that someonehasleft forothers willhave abiginfluencewhenthe good person has died, one of the formsof gratitude doneby thepeopleof Cihideungfor the karahun-kahurun who have given and left goodness to their descendants by performing rituals to honor these karuhun. becauseaccording to theirbeliefs spirits and spirits who occupy their placecan givegood or bad. So this ritualof mourning aims to be a watchfor thepeopleof Cihideungto rid themselves of bad traits, in order to get good and be kept away from the bad things that happen to them when they live their lives, and to respecttheirspirits. 
Ngabungbangis silentoutside the buildingwith stayingup allnightespeciallyin a sacred place on the full moon calendar which is usually doneon the month of mulud. Thisritualis performed in themonth of Mulud by thepeopleof Cihideungbecausein themonthof the birthof the Prophet Muhammad SAW as a holy personpurifiedby the Most Holy andalso as rahmatanlil'alamin, from here thecommunity made the Mulud month a moment to cleanse themselves, stay away from reinforcements, and honoring his spiritswith mediathatwereused assymbols inrituals. Thisritualis performedoncea yearon the 14 th of Mulud, whichis technically performedat nightafter theeveningprayer untildawn.

\section{Place of Implementation}

Pancuran 12 is a source of water that never dries even though there is a long dry season, so that more local people use it as daily necessities such as for drinking water, washing clothes, containers, mosques and so on, andeven a source of waterfor adjoining villages like the village of cigugur duringthe dry season bybeingsuckedup witha dieselengine ina car and the waterneverdries.

"Accordingto the shower" as a childaround theyear 65 has been used by the community so that its existencehas alwaysexisted. Thelandandthefountain 12 areprivatelyowned, haji mulya andbu haji eneng, who are the richestpeoplein Cihideungand are nowbequeathedto theirchildren. The fountain comes out on its own without being made by human hands. According to him, there are several names of showers in answerarat such as shower 8 , shower 7 and shower 12 , meaning it means that 8 returns to tofu, 7 returns to the day, and 12 returns to the moon. Now there are changes inshower 12 where the water thatcomesout throughthespringis accommodatedusing a large tub made of walls, then made 12 showers made of iron so that water flows from the tub when used by residents, aswellas 3 righthand showerused by mentakenfrom a largetub through the front of the canopy, now thecanopy has also beenturnedinto a buildingmade of walls and no longer standingon water. Thereis somethingdifferentin every waterthatcomes outof the shower 12 even though it comes from one sourceof waterand one basin, according to him, theshower of lontong lontong is niceto see an wetan tinarasana. the tipof the kulon becausethe water coming from the shower next to the wetan feels bland and sour". Interview with Abah Aling (Elders in Cihideung Village, Parongpong Subdistrict, West Bandung Regency) 20 November 2017. Forpeople outside of theshower 12 is sacred, so it oftengetsvisitorsreadingprayers before bathing. according to ema abah's wife, it isconsidered normalbecausethe name is "endeavorto kedah kakesangan tea, sabab according to elderskapungkur pami ihtiarkedahnu ismoremeh kakesangan". Accordingto the newcomers why they came to the fountain 12 because they got the advice or instructions to come there. Interview with Ema, wife of Abah Aling (Elder in Cihideung Village, Parongpong District, WestBandung Regency) 20 November 2017."

Besidesbeingusedfor theneeds of this place, it isalso usedasa ritualplaceto getblessings orideals from visitors who come, so for virgins thereis an aim to quickly geta mateby bathingin the middle of the night thenproceedwiththemidnightprayer and dhikrin the canopyandetc. there is also the experience of people who bathe when the shower waterflowsandtouches theback feels like coconutwater, leeur or water so that the flow over the back that runs smoothly. Ngabungbang at home abah is currently being held in a largefamily home whereevery familymembercooks a yellowriceconeandis takento theplace of the family elders where there gather all family members, ranging from uyut, grandfather nanek, children, grandchildren andother siblings.

"According to the ema's narrative" baheula mah mengabungbang tea swung in the midst of the elders of the family terrace in 7 sourcesof cai fountain, sabab ayeuna mah tos inical may have hiji deui nyaeta shower 12 "(Interview with Ema wife Abah Aling (Elders in Cihideung village, Parongpong District, West Bandung Regency) 20 November 2017" 
According to the explanation above, the place to hold the ngabungbang ritual in Cihideung was different from what was donenow. Whereas atpresent theritualis only performed inthe homes of elders of each familyandalso in the mosque.
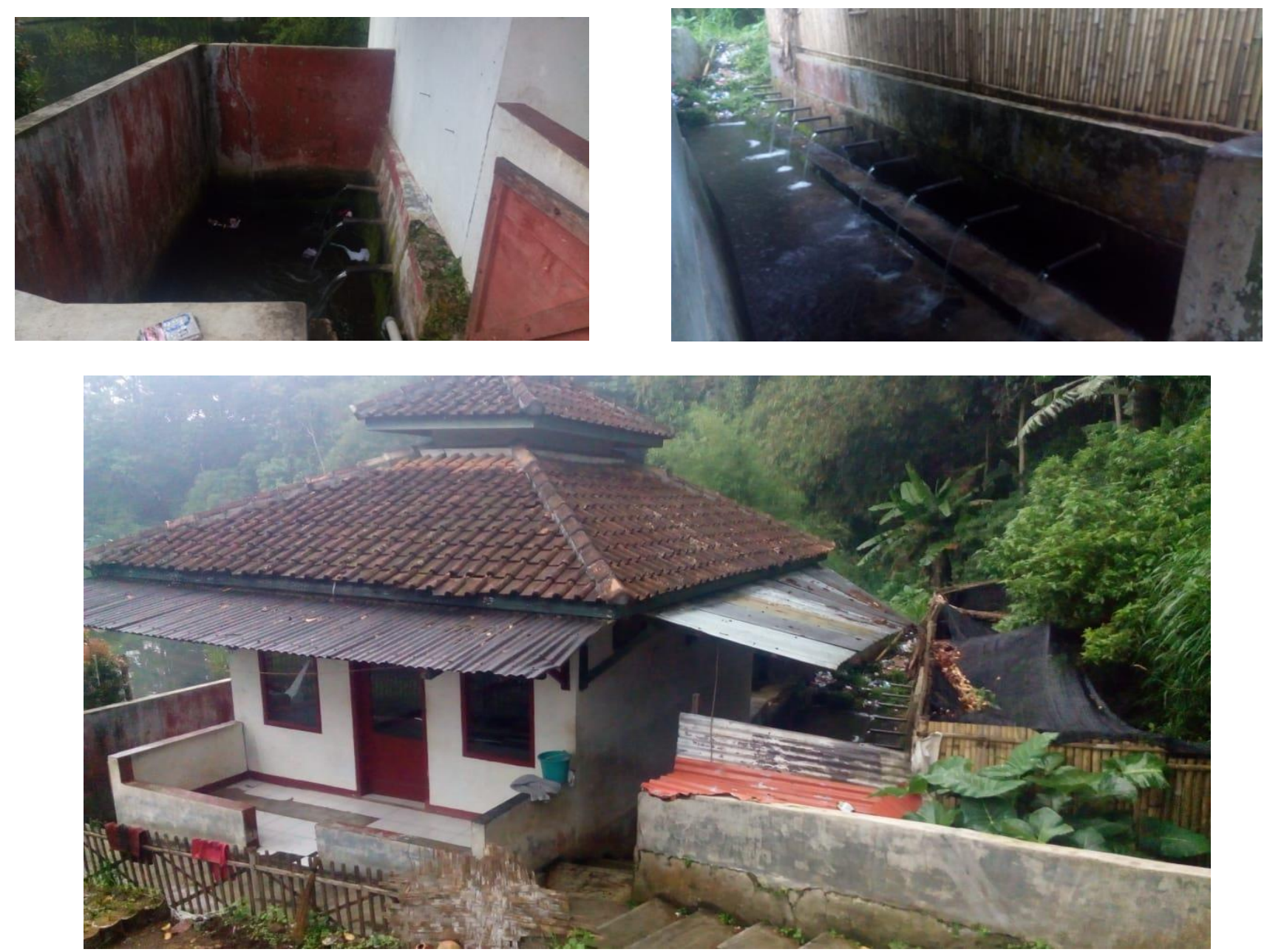

Figure 1. Homes and mosque

In the past thengabungbangwascarriedoutat thevillageelders' house, because the late elders left the cultural heritage of the ngabungbang ritual and the ngabungbang was moved to the mosque. In the readingof prayerscalledmuludprayers mustbe read throughthetext even though someonewho reads it has memorizedor catalarzed. This is intended to avoidforgetting and missedreading, it isin thisannual activitythathe wants to introducehisdescendants abouttheculture of mourning.

"Abahsaid" Mangkasatungtung abahmahstillinhaledmahmoal ngalengitkeun karuhuntraditions, jeung etaoge nu I abah dugikeunkakaturunan abahsadayanatong untilmohokeun, wayahnaurangmah kudu tradition is guarded, because our goals are all the same in the end of heaven, daah breathe in the world mahkumahaurang intheworld, pami katingalnatiduniamahurangtea inthe graveyardof heaven, but in essence i ngarencangan hisuretacharityactivities inthe world, thenfor abahliving in the grave of mah ludengteukeeungeun (Muttaqien, 2019). Dina's eyesareinhaledmah tong bogageregesfried batureven thoughthank 
God dahahah, never mind thefree, wedon't wantto hate hatebatur will definitely bale megusti. Interview with Abah Aling(Elders in Cihideung Village, Parongpong District, West Bandung Regency) 20 November $2017 "$

\section{Carrying out the ritual}

In organizing this ritual related to the time and place determined by the elders of each family, specifically thetime isseen through the Sundanese datecount, theninformedto all members of his family to prepareeverythingneeded in theritual process later. Themedia thatmust be prepared by eachsmall family memberis cone with side dishes andwater thathas been sprinkledwithcolorful flowers. From this, every smallfamily sincethe morning of the 14 th muludtheyhave been busy to make themedia which isa conditionfor theimplementation of theritual.

Other mediain this ritual are offerings for thekaruhunconsistingof pait coffee, kawung sugar, cai herang, rujakeun, cai bodas, beas, artos, uyah, bodas porridgejeung porur beureum, heirloomsthatwillbe flush, vehicle keys whichare themeans for lookingfor life, yasinbook, andmuludprayer that mustberead through the text even if someone who reads it has memorized it. This intends to avoid forgetting and missed reading.
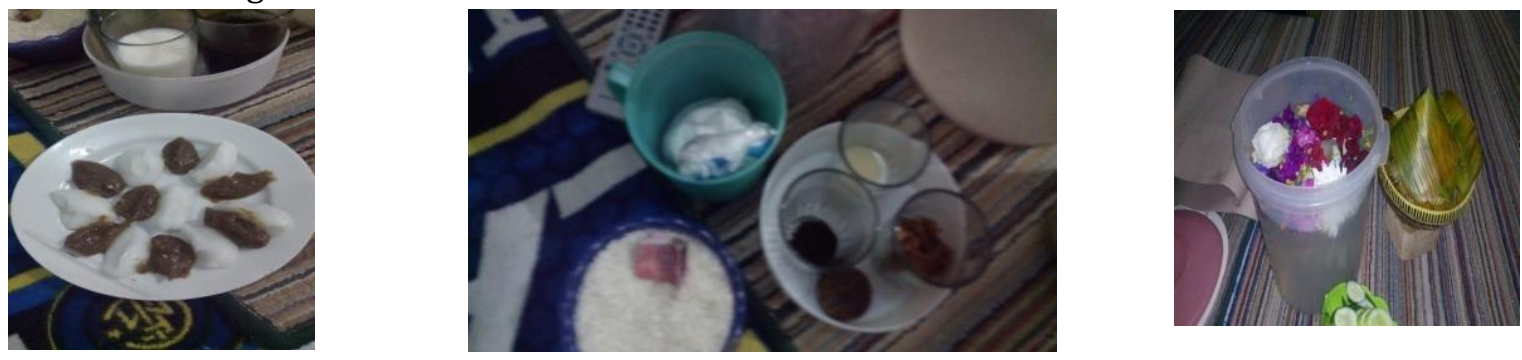

Figure 2. Ritual Media

In this ritual there iswhatis called themuludgapand the Kabulangap. Gapar mulud is a procession where peoplebreak the cone-shapedricecone tipwhich means thatwe arealwaysin good health, while the Kabulan gapis a pieceof the cone-tip and thensomeone is recommendedto takea little eventhough only threegrainsof rice, butshouldup sakeupeulwhich is thenusedup / smokedandeatenso that it enters the throat without chewing and breathing, this is intended to gainintelligence.

The offerings areofferedto the brothers who according to them arenot theessenceof theofferings given butthe essenceof the offerings thatwill be enjoyedby the spirits of theancestors.

\section{The course of the ritual}

On the day of implementation beforesunset, small family membersstartarriving untiltheevening time, they bring the whole family members starting from husband and wife and children, even close neighbors are also participating. They began to arrive by bringing yellow rice cone with side dishes that differ depending onthewishesof eachfamily, and also carrying a container filledwithwater thathasbeen sprinkled by flowers. The key to the vehicleownedby eachfamilymemberis put into thewaterthat has been sprinkled with the flower. All ritual media are stored in a large family crowd. Yellow rice stacks should beclosedand shouldonly be openedwhenthereis a specialprayerreadby extendedfamilyelders. 


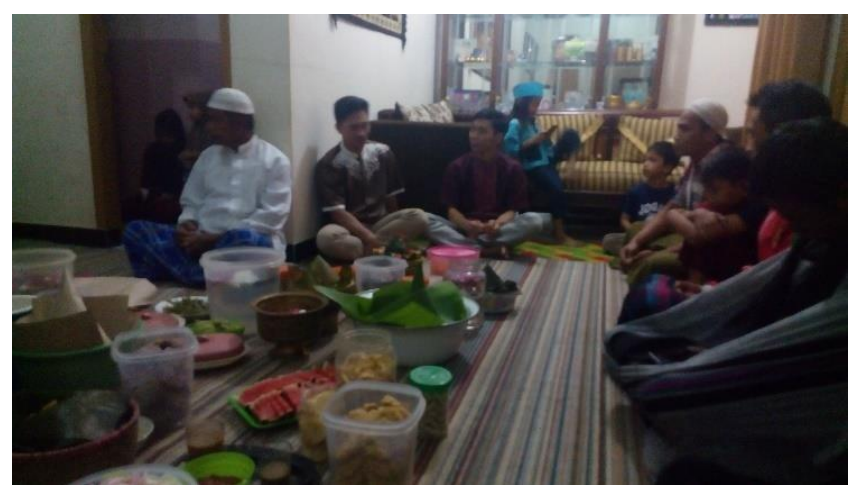

Figure 3. Family

After all gathered, thenthe elder as theelders gavea lectureand the purpose of the ngabungbang ritual, then continued with the reading of the tawasul which is praying for the pious people and the dignitaries they respect, then all members present read the yasin, then recite the prayer beads, tahmid, takbir, tahlil, andblessings to theprophettogether, then endedwitha special prayer readbyfamily elders, when the prayerswerereadup to the sentence Gapar muludall the families presentwerescrambling to break thetipof the coneclosestto thesitting position, thentheelder continuedhisprayer and atthetime of reading untilthe sentenceis filled with Kabulan, all family memberstakea mouthful of Gapud Muludan which is thensucked andthen swallowedby holding theirbreath.

After the ritual, the program will continue with the meal of food brought by each family, and is allowed to takedishesfrom other families asa form of sharing. Next they talk to each otherina freecontext not related to ritual. The water that has been prayed for is then brought to their respective homes, then the water is usedin a bath.

"How to bathe ngabungbang that is done at the same time at $12 \mathrm{pm}$ If not possible then in the morning by pouringwater 3 times onthe headby reading the Allahuakbarbismillahon eachsplash, this is almost the same as a person who tawaf when he gets to the pillars of Hajar Aswad and harmonious yamani say Allahuakbar bismillah, while the amount of 3 times splash equated like a person who performs ablution with 3 times on each member of ablution, which then is not dried using a towel, meaning that barakawater absorbs into thebody. Interviewwith Abah Aling (Elders in Cihideung Village, Parongpong Subdistrict, West Bandung Regency) December 1,2017. Thething felt by ema when bathing with mulud flowers felt something different like cai na the nyecep, and the word abah "pretentious ngagurubuk munmymother cai eta the". Theageof theflowercaiwas brought to the shower so that the residents bathed there and specifically for the girls and virgins they went around bathing in 7 water springs, 12 showers, cai tapering, mapena showers, parmi showers, ciguruwung showers, ciawitali springs, cai kwutu cai intended so that they are safe and quickly get a mate. Anotherritualperformed isnyimbeI which isto bathe heirlooms suchas sword dagger etc. which are now replaced with vehicle keys. Next is the gap and Kabulan ritual of ngabungbang in the sun to dry, then sprinkled around the house, according to customary understanding it servesto avoid thedistress of naturaldisasters such as lingsor, rain, flood, fire and so forth. Interview with Ema, wife of Abah Aling (Elder in Cihideung Village, Parongpong District, West Bandung Regency) 1 December 2017" 


\section{The Meaning contained in the Ritual Element}

The elements that exist in the ngabungbang ritual are symbols, the point is that in the ritual elementsthereis a noblevalue of local wisdom whichis usedas a guideline of life outlook so thatwe are not wrong in moving. The following elements in theceremony thathave meaning, namely: Gaparmulud, Kabar gap, Nyimbel Bubur beureum jeung bodas, Coffee pait, kawung sugar, milk, jeung cai asak herang 'bittercoffee, brown sugar, milk, andclearboiledwater' , Uyah 'salt', tumpeng 'nasi tumpeng', Beasjeung money 'riceandmoney'.

\section{CONCLUSION}

To respond to the ups and downs of state recognition of adherents of indigenous religions. Followers of belief in God Almighty endeavor in various ways to defend the teachings of their ancestors. No exception, followers of the Djawa Sunda Religion in Kuningan Cigugur. They seek to build innovative and creativestrategies thatmorph into newforms (prospectors), defendfor the stability of the existence of the organization (defenders), deal with internal consolidation ways to find the organization's safe position (analyzers), or are forced to succumb because of external threats or pressures and no power to fight it (reactors). From someof theefforts describedearlier, it canbe analyzed that adherentsof Madrais can be categorizedas organizations with prospectorsanddefenders. Althoughinsome partsalso included types of analyzers and reactors. The affiliation of ADS / PACKU / AKUR with government and nongovernment organizations (BKKI, Director General of BHK, AMAN, ICRP, ANBTI) proves that those who adhere to the teachings of Madrais are categorized as defenders, meaning to survive by joining other organizations for organizational stability. Besides organizing the ceren seren taun ceremony, which is intendedto maintain theexistence of theorganization, it also includesthe category of defenders. Asfor the establishmentof the Tri Mulya Foundation, the change in thename of theorganizationfrom ADS to PACKU then became AKUR, and the "struggle" of Paseban from Catholicism, in thiscase, enteredtheprospector's type because they dared to make new and innovative and creative breakthroughs and changes. The activity of rearranging Madrais' teachings by Prince Jatikusumah is in the category of analyzers, which means trying to internally consolidate the organization by strengthening the foundations of the learning so that it is easier for followers to understand. Included in this category are also sending officers from Cigugur in marriages performed by followers in areas such as Ciamis, Banjar, Tasikmalaya, Garut, and Cireundeu. Thetypeof reactorscanbeseen inthecaseof the dissolutionof ADS in 1964, the banof PACKU in 1982, and the ban on the celebration of serenum for about 17 years. Although the ceremony of seren taun is carriedout clandestinely.

\section{REFERENCES}

Afrianti, D. (2019). Transformation of the Spread of the Manunggaling Kawula lan Gusti Concept in Javanese Society from the 16th Century AD to the 21st Century AD. International Journal of Islamic Khazanah, 9(1), 29-34.

Ahimsa-Putra, H. S. (2012). Fenomenologi agama: Pendekatan Fenomenologi untuk memahami agama. Walisongo: Jurnal Penelitian Sosial Keagamaan, 20(2), 271-304.

Archer, M. S., \& Elder-Vass, D. (2012). Cultural system or norm circles? An exchange. European Journal of Social Theory, 15(1), 93-115.

Ghani, A. M. A. (2019). Metode Diskusi Lembaga Kajian dan Pengembangan Sumberdaya Manusia Nahdlatul Ulama. Khazanah Sosial, 1(1), 1-14.

Herlinawati, L. (2011). Ngaruwat Solokan di Desa Cihideung Kecamatan Parongpong Kabupaten Bandung Barat. Patanjala,3(2), 296-314.

Ismail, A. (2012). Agama nelayan: pergumulan Islam dengan budaya lokal. Pustaka Pelajar. 
Kahmad, D. H. (2011). Sosiologi agama: potret agama dalam dinamika konflik, pluralisme dan modernitas. Pustaka Setia.

Koentjaraningrat. (1990). Beberapa pokok antropologi sosial. Dian Rakyat.

Mufid, A. S. (2006). Tangklukan, abangan, dan tarekat: Kebangkitan agama di Jawa. Yayasan Obor Indonesia.

Muttaqien, Z. (2019). Peran Perempuan dalam Tradisi Sunda Wiwitan. Khazanah Theologia, 1(1), 23-39.

Petrof, S. (2015). Religious Broadcasting-Between Sacred and Profane toward a ritualized mystification. Journal for the Study of Religions and Ideologies, 14(40), 92-111.

Riis, O., \& Woodhead, L. (2010). A sociology of religious emotion. Oxford University Press.

Sugiyono. (2013). Metode Penelitian Pendidikan Pendekatan Kauntitatif, kualitatif dan R\&D. Bandung: Alfabeta.

Syam, N. (2005). Islam pesisir. LKiS Pelangi Aksara.

Wibowo, A. (2019). Pola Komunikasi Masyarakat Adat. Khazanah Sosial, 1(1), 15-31.

Wawancara dengan Abah aling, sesepuh desa Cihideung.

Wawancara dengan Ema (istri abah Aling), sesepuh desa cihideung 